\title{
Albania, an ex-communist country during the transition period: problems and challenges*
}

\author{
Vasilika Kume / Shyqyri Llaci*
}

This paper intends to give a brief history of the Albanian Economy before and during the transition period, to analyze the transformation of Albanian Society toward an economy based on private property and the free initiative of free people, and to highlight some of the problems and challenges Albania is currently facing. The aim of this article is to tell what could be some of the ways for a fast recovery and steady development of our country.

In diesem Artikel wird die Geschichte der albanischen Ökonomie vor und während der Übergangsperiode kurz dargestellt. Damit verbunden ist die Analyse der Umwandlung der albanischen Gesellschaft hin zu einer Ökonomie, die auf Privateigentum und der freien Initiative freier Menschen beruht, wobei einige Probleme und Herausforderungen aufgezeigt werden, die in Albanien aktuell sind. In diesem Artikel sollen einige der Wege, die zu einer schnellen Erholung und nachhaltigen Entwicklung unseres Landes führen könnten, gewiesen werden.

\footnotetext{
* Manuscript received: 5.3.1999, revised: 10.2.2000, accepted: 14.2.2000;

** Shyqyri Llaci, born 1959, Prof.Assoc. Dr., Senior lecturer in "Business Organization and Management" and "Theory of Organization and Management". Department of Management, Faculty of Economics (Tirana University). Major areas of interest: Business Management, Organizational Change and Development, Theory of Management.

Vasilika Kume, born 1955, Prof.Assoc. Dr., Senior lecturer in "Strategic Management" and "Managerial Decision Making". Department of Management, Faculty of Economics (Tirana University). Major areas of interest: Comparative Organizational Strategies. Management in Joint Ventures, Managing Change.
} 


\section{Background on Albania}

Albania is located in the Balkan Peninsula in southeastern Europe, on the Eastern Shore of the Strait of Otranto across from the "boot heel" of Italy. Former Yugoslavia borders on the north and east, Greece on the South, and the Adriatic and Ionian seas on the West. The smallest of the Balkan Countries, it has an area of about 28, 000 square meters.

Albania crosses a vertical line extended from South to North, to link thus Northern and Central Europe with one of its extremities, Greece

Albania is a predominantly mountainous country. Roughly, three-fourths of its territory in the north, south and central regions, consist of mountains and hills full of streams, rivers and lakes. In contrast to the rugged terrain and limited arable land in the mountainous regions, the western plains beside the Adriatic sea, endow Albania with a wealth of natural resources, including chromium (5 percent of the total world reserves), copper, iron, oil, bauxite, phosphate, asbestos, coal, marble and clays. Since the transition began about eight years ago, the mining of these materials has been barely operational.

In one pagan legend of Albanians, it is said that, after creating the world, God was left with a sack of stones and rocks and did not know where to throw it. He shook the sack once or twice unresolvedly and threw it down on lands where forever Albanians live.

This story is told by Albanians whenever they are fed up with troubles they have to encounter on this strip of land, not so wide, rough mountains, historically poor and permanently attacked by others, while others, even in two thousand years, never have been attacked by them. And whenever they escape bad luck, they repent for harsh words and call their Motherland a beautiful and brittle bride, looking to the future, which for Albanian brides as for Albania itself is insecure and full of puzzles.

The distinct geographic strategic position has confronted the Albanian people with long and violent occupations by ambitious peoples like ancient Romans, Turks in the Middle Ages, Italians and Germans in our Century. It is a fact already recognized now by Albanians and foreign analysts that the five-century occupation of Albania by the Ottoman Empire has been a decisive factor for the destruction of the Albanian Economy.

Albanians have suffered too much from oppression during their history. One feeling was however not suppressed, and this gradually became a main feature of Albanians: national feeling. As centuries were passing, in the complicated Balkan context, where oriental and western cultures were differentiated and matched, where entire populations were assimilated and new ones acquired, this feeling grew stronger. Representatives of the Albanian Renaissance, a handful of idealists in the century-long darkness of the Ottoman Empire, worked hard to raise national consciousness, permanently pressing on this idea. 
Only in 1912, Albania won independence from the Turkish Empire. Neither the monarchic regime of King Zog, nor the communists of E. Hoxha could make Albania a European country, as it deserved to be a long time ago.

Cultivated patriotic and collectivist sentiment has been more successfully used by Albanian communists than in other eastern countries, for Albania was rather compact. They found a ready-made basis to establish their totalitarian regime, which is closer to perfection in peoples with strong collectivist sentiment, like in Germans for instance or in Serbians, as they were realized from relatively tolerant obligations of Tito's Yugoslavia.

During the 11-year period of the kingdom (1928-1939), Albania could not create the capitalist mentality as it existed in civilized Europe. Even those few capitalist elements created during these years were eliminated by the communist regime "rich" with the traditions of an extremely centralized economy. This regime not only extinguished the capitalist seed inherited from the past, but it did not allow at all their recreation and its access as happened in Hungary, Poland and elsewhere. So, from this point of view in Albania, there has existed not simply institutional emptiness, but also emptiness in the mentality of this society.

\section{The Albanian economy during the communist regime}

The Albanian communist regime (1945 - 1990) has often been defined as "the stronghold of Stalinism". In fact, the productive model applied after World War 2 by Enver Hoxha, has its roots in Stalin's policy, whose salient characteristics were:

- Authoritarian and centralized economic planning.

- Industrialization giving pre-eminence to heavy industry.

- Forced collectivization of agriculture.

- Nationalization of industry and commerce.

- The use of coercion through police and secret services to ensure strict control over society.

- Frequent recourse to political "purges".

- Absolute hegemony of the communist party.

- The strengthening and extension of the administrative and bureaucratic apparatus, which served as "conveyer belts" to the party leadership, and

- The leader's personality cult.

However, the peculiarity of Albanian communism, with respect to other eastern bloc countries, came from the strong nationalistic push for independence which 
conditioned all the main decisions taken, regarding both domestic and foreign policy, so much so that it was to be defined "National Communism".

Indeed, the system of central planning of the economy and the control, applied by the State Party, had no equal in the whole of Eastern Europe. The choice of a strong centralizing government and recourse to radical solutions in building up the socialist system, were natural in a country which had known conditions similar to anarchy, weakened by clan and tribe sectarianism, where poverty, illiteracy and superstition predominated, and whose economic life was primitive and disorganized. In the old semi-feudal society, the workers lacked the discipline and industriousness necessary for the country's rapid development. A strong centralized state was therefore considered essential for transforming the country's manpower into a united workforce, overcoming the problem of negligence and individualism, ensuring a more rapid growth in industrialization and to fight possible opposition.

The policy of self-reliance and the extreme isolation of the country, especially during the 1970s and 1980s brought about the interruption of financial support from abroad, so hindering every kind of accumulation of resources for capital investment. With an industry based upon old technology and with a backward agriculture, the signs of the crisis became obvious in the 1980s and it burst out in all its components in the year 1990. Very high inflation, a deep decrease of the GDP (about 50 percent), the accelerated growth of unemployment, as well as the general disintegration of the balance of foreign trade, in the period 19911992, were the main consequences of economic collapse.

The general crisis with economic, political and social dimensions was accompanied by a people's uprising, which having as vanguard the movement of the students in December 1990, forced the communist leadership to accept political pluralism. The communist party won this election, but the wave of popular protests presented a big obstacle for it to govern the country. The first non-communist government, based on an agreement between different political parties was created in June 1991. This government had a short life of only five months. It only started the liberalization of prices, of the rate of exchange, the privatization of land and of some public services.

\section{The transformation of Albanian society toward the free market economy.}

Numerous analysts are investigating factors and causes of collapse of the socialist system in eastern countries. Without going into depth in such an article, we would like to deal with those occurrences, which follow such major shifts as the overturning of political and social systems. Maybe it is one of the rare cases in the history of mankind that one system replaces its opposite without bloody revolutions and massive victims. 
Perhaps the most important and true change this time evolved within the human being. Imagine a person born in 1947. At kindergarten, where he is sent at least xat the age of three years old, the first verse learnt is dedicated to the Labor Party, which according to it is his second mother. As he grows up, he learns in school and everywhere he goes, new concepts about communism as the best system in the world, about the bad people of this world, that more or less are rich people, blood suckers, etc.

What he hears from parents is, be careful, don't talk outside about what you hear at home, don't talk to that person because he has a bad biography. (Which means he has relatives who have been rich or connected with fascists in the past).

The person grows up and goes to work. He spends his youth in the agitation of excitement for building Socialist Fatherland. He begins to be afraid quite early. Afraid of slips of the tongue, of classmates, of social curb, of relatives that might be imprudent regarding their conviction and devotion to the party and might make a blunder, thus be interned and imprisoned, then necessarily he himself would be interned and imprisoned.

Imagine now how these people are confronted with a reality entirely different, quite opposite of the one they have lived in all their life?

In various aspects, Albania has represented a unique case compared with other eastern countries, an extreme version of Marxism-Leninism with numerous local ties linked with both the strong national identity of the Albanians and with Hoxha's attempt to build a communist society of Albanian nature.

Even "Albanian transition", as far as the strength of its impact and the speed of the transformation is concerned, might be seen as a kind of an extreme case within the framework of the more general transformation phenomenon occurring in eastern countries.

Albania was the latest communist country that entered the road of economic transformation. Apart from the ups-and-downs and the intensity of the political processes in Albania, which undoubtedly has its reflection in the trend of economic reform, the first serious economic steps toward a market-oriented economy began after the first pluralistic elections in March 1991. This might be considered as the first phase of the Albanian economic reform accompanied by a lot of controversies, confusion, half measures and, above all, a virtual political instability.

The general elections of March 22, 1992, were finalized by the victory of the Democratic Party. A new government assumed office in April 1992, starting a new comprehensive reform program. The program was carried out in two phases. From mid-1992 to mid-1993, during a one-year program, fiscal and monetary control combined with comprehensive price and exchange system reforms was introduced. The program was generously supported by various 
international financial and technical sources. An important element was the support and remittances sent by the Albanians working abroad. After the good implementation of the almost one year emergency program, a medium term program was presented in the parliament in November 1993 for the 1993-1996 period.

Until 1996, Albania seemed to belong to the transition "success stories". The GDP evolution placed Albania in the group of leaders. The growth in 1995 was reported at 13.4 percent, one of the highest rates in the world. After a severe drop between 1990 and 1992 to 65 percent of the 1990 level, the economy was rapidly growing since 1993 and reached already 86 percent of the level of 1990 . However, with $675 \$$ of GDP per capita in 1995 , this small country of 3.4 million citizens, remained the poorest in Europe. Two other indicators were impressive: the inflation rate, which was 31 percent in 1993, 16 percent in 1994, 6 percent in 1995. And with a private sector, representing at least 60 percent of the GDP, Albania could be considered as one of the most privatized transition countries, comparable to Poland and Hungary.

Other indicators that would present a more balanced picture could confirm these results. According to foreign investment, the place of Albania in that period was rather modest, with a global stock of 130 million FDI, i.e. $38 \$$ per capita. However, this level was comparable with Poland or Croatia. The main investors were Italy and Greece, mainly in light industry (textile and shoes) and infrastructure. There were other investments in tourism (Austria, France). EU (EBRD, Phare Program, and EIB) mainly provided foreign funding. At the end of 1995, regarding the synthetic transition indicator (the sum of EBRD indices), Albania rated at 21, i.e. rather far from the leaders with 31 (Czech Republic and Hungary). The rank of Albania was equal to Uzbekistan, just behind Macedonia and Romania, and just before Ukraine.

As the table shows, Albania's good marks were on the easiest (but very important) items: price and trade liberalization, small privatization, (the indicators do not consider the specific privatization in agriculture; if they did, Albania's image would be better). The weaknesses were on the institutional side of transition, on large privatization and enterprise restructuring, all items reflecting the depth of the development of the market economy. However, the steps that were made were sufficient to launch private initiative and to start to modernize the country. In that time, Albania has started to build the financial sector. Two of the three state banks were planned to be privatized by 1997, and five foreign banks were operating in the country. In April 1996, the Anglo Adriatic Fund, the first private investment fund for privatization bondholders was created. In May 1996, a first stock market, trading only privatization government bonds, started. 


\begin{tabular}{|l|c|c|c|c|}
\hline & 1 & 2 & 3 & 4 \\
\hline Large-scale privatization & & $\mathrm{X}$ & & \\
\hline Small-scale privatization & & & & $\mathrm{X}$ \\
\hline Enterprise restructuring & & $\mathrm{X}$ & & \\
\hline Price liberalization & & & $\mathrm{X}$ & \\
\hline Trade and foreign exchange system & & & & $\mathrm{X}$ \\
\hline Competition policy & $\mathrm{X}$ & & & \\
\hline Securities markets \& non bank financial institutions & $\mathrm{X}$ & & & \\
\hline Legal rules of investments & & $\mathrm{X}$ & & \\
\hline
\end{tabular}

How to characterize the Albanian transition? How to explain its success? There are three features to the Albanian path to the market economy: strong support of the population, a radical liberal orientation, and a strong extroversion of the economy.

The communist regime in Albania was especially tough and the willingness of the population to leave the past and to enter the market economy system was high. It gives strong political credit to post-communist government.

Moreover, this political credit allowed the government to launch a radical reform. The Albanian reform could be characterized as quick and liberal. The price and trade liberalization, the cut of subsidies happened in a few months and the economic policy became very orthodox according to IMF recommendations. The dominant philosophy was the less state, the better. The concept of privatization was also radical. The aim to privatize almost everything would reduce the state sector to the smallest minimum. The result of this policy was strong growth and disequilibrium. The shock for the economy was very hard, industrial production fell in 1992 by 60 percent and 10 percent in 1993. The GDP drop was 35 percent; real wages fell 30 percent between 1990 and 1993. Unemployment jumped officially to 26.5 percent at the end of 1992, and in cities, the global underemployment was at least twice as high: 50 percent of the active population was jobless. But already in 1993, GDP increased. Growth was led by agriculture, construction and by small private services.

The third feature of Albanian reform is its extroversion. It means that inside Albania consumption was much higher than production: the differences were provided by outside sources, by private transfers and emigration. Aid was equivalent to 40 percent of GDP in 1992, 20 percent in 1993 and 12 percent in 1994. Incomes from 400,000 emigrants working in Greece and Italy, are 
estimated at 400 million \$ per year, 25 percent of GDP in 1994, and around 1520 percent in 1996.

However, apart from the success of the reform, the achievements of it appear to have been rather hollow. The financial sector remained underdeveloped and the willingness of the ex-government to implement reforms and comply with IMF and World Bank requirements masked reality. In fact, apparent economic success depended in large part on remittances from the workforce living abroad, large-scale smuggling and money laundering and the short-term profits from the pyramid schemes. This situation seemed to continue for a relatively long period.

But the situation began to get out of control since the contested elections of May 1996 and after the repression of the opposition in the main square of the capital ("Scanderbeg square"). In the economic context, it was the time when the pyramid schemes had passed their point of maturity and they were running fast toward bankruptcy. Within few months, everything built up for several years seemed to be ruined. All that international investment did not give its fruits and the country was again near the abyss. The land of the eagles began to be called the "land of kallashnikovi". During and after the election of June 1997, when the socialists and their allies won the absolute majority in the new parliament a "hot debate" is continuing about the causes of the Albanian catastrophe.

This debate continues even today and not only the politicians, but the analysts too, often do not share the same opinion for the evaluation of economic reform in Albania. Perhaps, this is due to the Albanian climate, which is loaded more than is necessary by political influences. Below we will try to escape from political influences of this kind and will stay within the frame of technocrats.

\section{The crisis of spring 1997 and its causes}

The years that came after the collapse of communist regimes in Eastern Europe and in Albania have shown clearly that the success or failure of reforming steps should be seen closely linked with the specific conditions, as well as with the historical experience of the region.

After this, a logical question is raised: Did Albania adopt the rules of the game according to that of a market economy, or was everything allowed to happen in a spontaneous way? What would have happened in an environment where the old rules did not exist any more and the new ones were drafted only on paper?

Let us try to analyze several moments of economic reform in Albania, with the aim of discovering the main causes of Albanian crisis.

In the chaotic situation, after the spring unrest of 1997 and the events that followed it, it seemed as if the economy, politics and the whole Albanian society were frozen and here and there, sunshine was seen at the end of the tunnel. In fact, the social agreement between the Albanian political forces and the 
successful realization of parliamentary elections were uncontested hopes for bringing into normalization the economic and social life of the country.

The causes of economic crisis in spring 1997 in Albania have been commented on in different ways from different analysts from a variety of areas and with different interests behind them. But let us try to analyze some of the main causes from the technocratic point of view:

- During these years, Albania has adopted a legal framework in which the local government was very closely controlled by the central government. So in Albania there was born a powerless local government, unable to present itself as the materialization of the people's will and accountable for the fundamental developments of the society itself.

- The governmental structure of the country (including the political opposition, too) which was the first to cope with the crises of pyramid schemes as a precursor of political demands that accompanied the civil unrest in FebruaryMarch 1997, was unable to absorb immediately the people's demands. It showed lack of flexibility and adopted with delay the political changes that were asked for by the people.

- The legal framework and the institutions started to be set up rapidly aiming at European standards. Such laws were very good often only on paper, because the level of their implementation in practice was very low. The question was not simply having a very modern legislation, but first of all implementing it in reality. It would be better to have a not very modern legal framework, but for it to be applicable and the citizens to see its implementation as a precondition to enter into the European family.

- Under the conditions of a relatively full legal framework, but not really in full implementation, in these first years of transition there were possible the creation and the existence of inefficient business networks, not competitive but in monopolist positions and even with discrimination power. This kind of business network, in which we can include the partial or full pyramid schemes, unbalanced in an obvious way the market ratios, the shift of capital from one branch to another and hindered the real economic growth of the country.

- The capital inherited from the socialist past could not be fully restructured in order to be suitable for the market economy, while the human capital, being unsuitable for the new economy, as well as, being forced from the poverty and lack of jobs was transferred to neighboring countries. It must not be forgotten here the "shrinking" of the state property through the special board's decisions for this purpose and the creation on this basis of a stratum of new entrepreneurs within a relatively short time. In many cases, this stratum was not able to put in use that part of national wealth that passed into their hands. First of all, this was due to lack of entrepreneurs' abilities to manage this wealth according to the rules of the market economy. 
- So, in these first years of transition there was not only an institutional and organization vacuum, but also a weak intervention of the state in the economy. In other words, the new system in which our country entered after the 1990s displayed a vacuum, which was filled by the informal sector in all the areas of activity. Here are the main causes for the large extension of this sector in the Albanian economy.

- Despite the reservations that we may have, the privatization of small and medium enterprises, should be considered as the most successful step toward the market economy on the road to setting up the institutions of this kind of economy. But the private property created in this period was not able to find the incentives of real economic growth, to stop the overconsumption and to reduce in an economic way the informal sector. As a consequence, the productive resources were not used with sufficient efficiency; consumption of all kinds was increased artificially and the economy went inevitably towards a general crisis.

- The reforms are successful when experts manage them with a mentality qualitatively different from that of the pre-democratic period. It was a fact, that in Albania the tradition of appointing people on the basis of party merits and not on professional ones continued. Coming from a fifty-year dictatorship, and used to managing with the old methods of dictate and of the party spirit, it was understandable that the Albanians would not change in a radical way and within few years this style of management. But this would be only half of a bad thing, if the people in power would have gathered around themselves those who were experts in their areas of knowledge. Professional knowledge in the specific jobs was replaced rapidly by the party militancy. It was in Albania where you could find a bank governor or a minister of finance from any profession, except for economist.

- The banking system, one of the most powerful institutions of the market economy, despite some small progressive steps, was left too far behind. Its incompetence caused the banks to lack credibility in the view of the Albanian businessmen and their money transactions instead of going through banks, passed in suitcases of cash from one businessman to another when doing business. In this way, the businessmen risked their business and their life at the same time. On the other hand, the banking system was supportive not only of the honest and competitive businesses, but also of the pseudo businesses, too. On behalf of their "businesses", many people got credit from banks and used them for other purposes. A part of them, tempted by the high interest rate of the pyramid schemes invested there the money they got for business from banks with the hope that without working they would have the chance to profit much more. It is thought that the inefficiency of the Albanian banks and the lack of private banks are some of the causes of the beginning of the Albanian crisis, which, as it may be known, started as a crisis of pyramid schemes. In such a ground, the pyramid schemes, where their existence was accelerated because of 
lack of proper legal framework, became quickly "successful" offering the incentives to start a massive epidemic among people. Two of the worst things of the pyramid schemes were:

First, "the robbery" of the savings of those working for years as refugees (and of their relatives) in Greece and Italy, and

Second, the education of the people with the motto that capitalism is the system of many surprises like that of being rich without working and within a short period of time. What the individuals in capitalist countries achieve after working hard for many years, the Albanians would achieve through tasting, in two or three years time, the fruits of their "money coupons" issued by the pyramid schemes.

The number of people that invested their money in these firms was very large. So their loss was transformed into an earthquake which gathered many things with it, while at a certain point (the people at the beginning were involved in economic protests) demanded even the resignation of the president and his party. All these protests happened in such a way that it will be remembered for a long time not only in Albania, but in the entire civilized world.

If we expand this analysis further into the capital market, we can say without any doubt that it is still in the infantile phase. The beginning of this market officially in May 1996, is an example of a delay in its development. In this market, mainly the banks and some other institutions, which like banks are state owned, operate. In this market, only obligations of the state are traded, but private companies are still not quoted. While the state is playing with itself, this market keeps out of the game the private sector.

- One of the great achievements, which was spoken also much about, was the freedom of thought and opposition of the specialists. But after a short time, it was clear that a thought and especially an economic thought different from those of the people with power began to be considered as anti reform, and as such, it should be left aside. Although with more space than before to express themselves and their ideas, the specialists found themselves within the frame decided from above, and the scientific debate for alternative solutions was replaced by conformism with what was approved from the top, from the new nomenclature.

- Corruption was raised into a system and nothing could be imagined to be realized without paying something under the counter. The government declared with all the channels of its voice the war against this phenomenon, but the result was too much ado about nothing.

- As far as the rights of the people and the image of Albania before international opinion led by American opinion are concerned, the situation continued to get worse and this was displayed openly after the election of May 1996, in "Scanderbeg square". The arena of the unequal "battle" of the 
governmental heavy machine, against the demonstration of the opposition forces for not knowing the results of the violated elections, was a show of almost unbelievable efforts of a party trying desperately to stay in power in an antidemocratic manner.

\section{A brief history of the development of pyramid schemes in Albania}

The beginning of the informal market in Albania was in the years 1991-1992. With the wind of change in economic, political and social life, with the development of the economy, to find the necessary capital for starting a business was a priority. As a first step, it was the development of the informal line of credits from friends and relatives. This helped the creation of the initial capital so necessary for the birth of a business.

Gradually, with the increase of income per capita, which is one of the necessary bases for the birth of pyramid schemes, in the period 1993-1994 there started to appear some phantom firms. Their activity was expanded by collecting incomes from small consumers, attracting them by offering interest rates higher than those of the bank offer. Meanwhile, their activity at that time was only locally focused. It has to be emphasized that the majority of these firms had also businesses like supermarkets, mines, livestock and agricultural activity, etc.

These firms took the pyramid form mainly during the years 1995-1996. Any profit level secured in economic activity could not justify the very high interest rates applied by them. Also, the competition between them for creditors brought an increase in very high levels of interest rates (from 5-50 percent in a month). At this point, the population trusted these firms, because of the fact that for some years they were paying back normally and correctly both the interests and the money invested.

The phenomenon of depositing money into these kinds of firms left its imprints on the banking system as well. At the beginning of 1996 the deposits of the population in the banks decreased drastically. Money was withdrawn from banks in order to be invested in such pyramid schemes. So, in total, bank deposits decreased by 100 percent.

The first signal issued by the government in November 1996 was not accepted by Albanians, who have been attracted very much by the peak that the interest rates of the pyramid schemes have reached.

Paradoxically, after the signals issued through state television, the flow of deposits increased even more. Some reasons for this paradox are:

- The long time of the activity of the pyramid schemes.

- The massive poverty and the desire to be rich within a short time.

- The lack of knowledge about this phenomenon 
- The identification of the activity of these firms with the government.

At the end of 1996, the first pyramid scheme ("Sude") went bankrupt. The people who had deposited their money there started demonstrations against the government accusing it of indifference and participation in the pyramid schemes. Finding it facing the people's pressure, the government ordered administratively two foundations "Populli" and "Xhaferri" to be closed down. The government also undertook the difficult task of distributing to the depositors the money they had invested in these two foundations. Instead of calming down the situation, these actions mixed the government totally with the bankruptcy of pyramid schemes.

The first months of 1997 brought with them a general unrest and the country was near catastrophe. The economy ceased its activity. Many businesses were destroyed. Prices increased by 50 percent. The Bank of Albania increased the amount of money in circulation by 45 percent within a period of six months. Meanwhile, the budget deficit by the end of November 1997 was 36.3 billion leks.

\section{The causes of the birth of pyramid schemes and the factors that helped them to a "long life"}

Pyramid schemes in Albania reached levels never noticed before in other countries. At the very beginning, their activity was not pure pyramid. At that time, we had an overlap of pyramid schemes and economic activity. But in many instances, people aimed at increasing their deposits because of serious housing problems. Due to lack of housing or bad living conditions, numerous families settled in the large cities, after selling their houses and invested the money in fund-raising schemes.

On the other hand, the base of the income turnover grew very much. The high interest absorbed not only domestic capital, but the incomes of the refugees, too. Monthly interest provided the living means for many families, primarily retired pensioners. But it holds true even for others, who wanted to multiply their initial amounts which reached alluring figures that formed the basis upon which people calculated their earnings without giving due consideration to the sums retrieved.

In many cases, the people had only "coupons" for their invested money, because in most cases they did not received their interest, but capitalized it. They imagined they possessed millions, while having only paper coupons. The psychology of interest re-depositing and capitalizing was aimed at obtaining better housing conditions or setting up new businesses and not simply surviving.

Pyramid schemes were characterized by:

- The multitude of forms in which they appeared in front of the depositors. From this perspective they can be grouped as follows: 
- Charity foundations: "Populli" and "Xhaferri" were the biggest.

- Investing companies like VEFA, Kamberi, Cenaj, Silva, etc.

- Companies with no other activity but money collection like "Sude".

- Unlike other countries where these schemes operated in specific zones or regions, in Albania they spread all over the country. Very soon it became a national phenomenon and did not remain merely a local one as it proved to be in Eastern European countries.

- The schemes developed in Albania stand out from the rest also for their duration. Political factors strongly intervened with economic factors, largely contributing to their longevity. It is estimated that the funds employed in the pyramid scheme amounted to approximately USD 1,2 billion, i.e. 60 percent of the Albanian 1996 GDP.

Amongst the factors that encouraged such schemes, we shall mention the following:

- Geographic position. This position is like a bridge that links East with West, Europe and Asia and for this reason Albania became very attractive for the speculators of drugs and guns, as well as for illegal emigrant businesses, etc. The southern environment, from a geographic point of view was very favorable for the birth of pyramid schemes.

- The massive poverty. After the "Berlin Wall" was broken in Albania, too, the Albanian people were ready to undertake a high risk for narrowing the economic differences with western countries. In such conditions, this game took such tragic dimensions, that many people sold their houses- the only real estate they possessed- with the hope of winning much more.

- The accumulation possibilities of the population. During the years 19941996, when the informal market took on large dimensions, the economy of the country was growing significantly. The incomes of the people were increasing as a result of :

o The growth of the GDP. (During the period 1994-1996, the savings of the population achieved a level of 15 percent of GDP, or nearly 350 million \$);

o The incomes from emigration. The incomes from emigration in 1995 were calculated to be about 250 million $\$$, while in 1996 this figure was thought to be 500 million $\$$ (an average 700-800 \$ per emigrant in a year);

o The incomes from aid and loans. After the events of 1991 and especially after March 1992, the neighbor countries, the European Community, the international financial institutions and other institutions have given to Albania aid and loans in relatively large amounts. A good part of this aid is used directly in favor of businesses, families, etc. But 
the entrance of monetary flows accompanies them. The National Agency of Foreign Investments calculates that an average of 150 million \$ each year have entered Albania from these sources.

- The non-positive role played by the massmedia, which advertised the interest rates applied by these firms and at the same time did not announce the public opinion of the danger.

- The reaction of international institutions like the International Monetary Fund, World Bank was with too much delay.

- It is thought that in that "long life" of the pyramids the money that comes from abroad for money laundering in Albania has had a significant impact.

- Lack of civil knowledge of the formal market. Over a period of 50 years, the structural elements of the formal market have not been in place; people had too little knowledge about business difficulties earning money; the situation was aggravated from the psychology prevailing in people's mentality, which expected the government to protect its citizens from risk. Furthermore, the pyramid schemes' bosses participated in official receptions and enjoyed the full support of all the media. Public perception, rooted in the difficult situation of Albania, that these companies were laundering money, reinforced the credibility of the returns they offered.

- Lack of a legal framework and the absence of legal institutions. The analysis bears out the conclusion that the backward Albanian financial system passively contributed to such a phenomenon; banks were just entering their restructuring process; there were neither private banks, nor stock exchanges or a full legal framework that could prevent public fund raising by non-licensed operators.

- This vacuum served as a fertile terrain for fund-raising company owners who still find supporters among senior officials who justify them by mixing up private borrowing with public savings.

- As to the effect politics had on the economy, we all are aware that every political group was forced to undertake a structural reformation of the economy, which involved both political and social costs. That is why the problems were not nipped in the bud, but increased until it became impossible to resolve them in a second stage. The attempts made to

Table 1: Growth in real GDP in Eastern Europe

\begin{tabular}{|l|l|l|l|l|l|l|l|c|}
\hline & \multicolumn{7}{|c|}{ Years } \\
\hline Country & 1990 & 1992 & 1994 & 1995 & 1996 & 1997 & $\begin{array}{c}\text { Estimated } \\
\text { level of real } \\
\text { GDP in } \\
1996\end{array}$ & $\begin{array}{c}\text { Projected } \\
\text { level of real } \\
\text { GDP in } \\
1997 \\
\end{array}$ \\
& & & & & $\begin{array}{c}\text { Esti- } \\
\text { mated }\end{array}$ & $\begin{array}{l}\text { Pro- } \\
\text { jectio } \\
\mathrm{n}\end{array}$ & $\begin{array}{c}1996=100) \\
(1989=100)\end{array}$ \\
\hline
\end{tabular}




\begin{tabular}{|l|c|c|c|c|c|c|c|c|}
\hline Albania & -10.0 & -7.2 & 9.4 & 8.9 & 8.2 & -15.0 & $\mathbf{8 5}$ & $\mathbf{7 3}$ \\
\hline Bulgaria & -9.1 & -7.3 & 1.8 & 2.1 & -10.9 & -7.0 & $\mathbf{6 7}$ & $\mathbf{6 3}$ \\
\hline Croatia & -6.9 & -11.1 & 0.6 & 1.7 & 4.2 & 5.0 & $\mathbf{7 0}$ & $\mathbf{7 4}$ \\
\hline Czech R. & -1.2 & -3.3 & 2.7 & 5.9 & 4.1 & 1.0 & $\mathbf{8 9}$ & $\mathbf{9 0}$ \\
\hline Estonia & -8.1 & -14.2 & -1.8 & 4.3 & 4.0 & 7.0 & $\mathbf{7 1}$ & $\mathbf{7 6}$ \\
\hline Macedonia & -9.9 & -21.1 & -4.0 & -1.4 & 1.1 & 2.0 & 55 & $\mathbf{5 6}$ \\
\hline Hungary & -3.5 & -3.1 & 2.9 & 1.5 & 1.0 & 3.0 & $\mathbf{8 6}$ & $\mathbf{8 9}$ \\
\hline Latvia & 2.9 & -34.9 & 0.6 & -0.8 & 2.8 & 3.4 & $\mathbf{5 2}$ & $\mathbf{5 4}$ \\
\hline Lithuania & -5.0 & -37.7 & 1.0 & 3.0 & 3.6 & 4.5 & $\mathbf{4 2}$ & $\mathbf{4 4}$ \\
\hline Poland & -11.6 & 2.6 & 5.2 & 7.0 & 6.0 & 5.5 & $\mathbf{1 0 4}$ & $\mathbf{1 1 0}$ \\
\hline Romania & -5.6 & -8.7 & 3.9 & 7.1 & 4.1 & -1.5 & $\mathbf{8 8}$ & $\mathbf{8 7}$ \\
\hline Slovak Rep. & -2.5 & -6.5 & 4.9 & 6.8 & 6.9 & 4.5 & $\mathbf{9 0}$ & $\mathbf{9 4}$ \\
\hline Slovenia & -4.7 & -5.5 & 5.3 & 4.1 & 3.1 & 4.0 & $\mathbf{9 5}$ & $\mathbf{9 9}$ \\
\hline Source: Tran & & -10.0 & \\
\hline
\end{tabular}

Source: Transition report 1997 EBRD, p. 115

protect this activity constituted a political error and figures demonstrate a strong correlation between the evolution of the political events and deposit levels. Such was the case with the rise in deposits in 1996, especially after the May 1996 elections.

\section{The overcoming of the crisis and the further development of the country on the road to the transformation of the economy}

The important indicators of the economic growth for the whole period of transition of Albania and particularly the years 1997-1998, compared with other countries in transition, are shown in the table 1.

According to data in this report, but also to our own calculation, it was foreseen that in 1997 the countries of Eastern Europe would achieve 95 percent of the GDP of the year 1989. Meanwhile, Albania achieved in 1996 only 85 percent of the 1989 GDP. For the year 1997, the forecast of the EBRD was not achieved, 
and what is worse, according to EBRD calculations Albania would achieve only 73 percent, because of the turbulent situation in the spring of 1997. It was only Poland, which during the year 1997 passed the level of GDP of the year 1989 by plus 10 percent.

In the context of the Eastern and Baltic states, 8 out of 14 analyzed in the year 1996 passed a growth rate of 4 and more percent, but three of them, Romania, Czech Republic and Albania had a very low or negative growth. The situation of Albania is explained by the events of spring 1997.

If we take into consideration the inflation rate, (the data published by INSTAT) at the beginning of 1992 it was 237 percent, while with a very fast decline in the year 1996 it reached the level of 6 percent. According to the evaluation of EBRD, for 1996, the level of inflation was 17 percent. This report, as well, shows that the projected inflation for 1997 was 42 percent. Returning again to the data presented by EBRD, the economic growth foreseen for several countries in 1998 is shown in table 2.

As can be seen from this table, the forecast for 13 countries is within the span from 1.9 percent to 8.9 percent. The lowest growth is foreseen in Romania, while the highest is in Albania.

The figures of table 3 show that the growth of GDP in 1998 is estimated at 10 percent. This indicates some good efforts in economic development. The other figures of this table indicate a modest improvement of main macroeconomic indicators in 1998.

But what would be some of the ways for a fast recovery and steady development of the country?

\section{1-The necessity of a monetary policy in accordance with the fiscal policy of the state}

The difficult situation our country passed through during 1997 and after it in 1998 , sets the demand for a wide program of objectives and measurements for a coordination of monetary and fiscal policy.

The achievement of final objectives towards macroeconomic stabilization requires from the Bank of Albania a tight monetary policy. But the implementation of such a policy may be unsuccessful if it is not coordinated with a tight fiscal policy as well, because we will have not a long-term stabilization if the starting point is only the emergency situation.

Table 2: GDP growth forecast for Eastern Europe

\begin{tabular}{|l|c|}
\hline Countries & GDP growth forecast for 1998 (Average) \\
\hline Albania & 8.9 \\
\hline
\end{tabular}




\begin{tabular}{|l|c|}
\hline Bulgaria & 2.2 \\
\hline Croatia & 5.2 \\
\hline Czech R. & 2.5 \\
\hline Estonia & 4.4 \\
\hline Macedonia & 5.1 \\
\hline Hungary & 4.0 \\
\hline Latvia & 4.6 \\
\hline Lithuania & 4.3 \\
\hline Poland & 5.0 \\
\hline Romania & 1.9 \\
\hline Slovak Rep. & 3.7 \\
\hline Slovenia & 4.3 \\
\hline
\end{tabular}

Table 3: Main macroeconomic indicators

\begin{tabular}{|l|c|c|c|c|c|c|c|c|c|}
\hline & 1990 & 1991 & 1992 & 1993 & 1994 & 1995 & 1996 & 1997 & 1998 \\
\hline $\begin{array}{l}\text { The real growth of } \\
\text { GDP in \% }\end{array}$ & -10 & -28 & -7.2 & 9.6 & 8.3 & 13.3 & 9.1 & -7 & 10 \\
\hline $\begin{array}{l}\text { GDP per capita } \\
\text { (thousands Leks) }\end{array}$ & 5.1 & 3.7 & 3.5 & 3.9 & 4.2 & 4.6 & 5.0 & 4.3 & 5.1 \\
\hline $\begin{array}{l}\text { Consumer price } \\
\text { index (CPI), in \% }\end{array}$ & & 22.7 & 76.4 & 100 & 115.8 & 122.8 & 144.1 & 204.8 & 225.3 \\
\hline
\end{tabular}




\begin{tabular}{|l|l|l|l|l|l|l|l|l|l|}
\hline $\begin{array}{l}\text { Foreign exchange } \\
\text { rate Lek/USD } \\
\text { (Average period) }\end{array}$ & & 75 & 102.1 & 94.7 & 92.8 & 104.5 & 149.1 & 163.3 \\
\hline $\begin{array}{l}\text { Budget revenues in } \\
\% \text { of GDP }\end{array}$ & 46.8 & 31.5 & 24.7 & 26.7 & 24.1 & 23.5 & 18.5 & 17.3 & 22.1 \\
\hline $\begin{array}{l}\text { Budget } \\
\text { expenditures in \% } \\
\text { of GDP }\end{array}$ & 62.1 & 62.2 & 46.2 & 40,4 & 33.1 & 32.3 & 28.8 & 29.5 & 35.8 \\
\hline $\begin{array}{l}\text { Total budget deficit } \\
\text { in \% of GDP }\end{array}$ & 15.4 & 30.7 & 21.5 & 13.7 & 9 & 8.7 & 11.3 & 12.2 & 13.8 \\
\hline Inflation in \% & & & 237 & 31 & 16 & 6 & 17 & 110 & 40 \\
\hline
\end{tabular}

Source: “Fiscal statistics of government”, Tirana, March 1998.

\section{2-The reduction of the informal sector}

The long-term development of Albanian business is closely linked with the reduction and elimination of the informal sector, too. (The informal sector is that part of economic activity that is realized partly or totally outside the influence and the authority of the law). An obvious influence in the development of this sector has derived from the main macroeconomic steps undertaken in the economy during these first years of transition. Here can be mentioned especially the steps linked with the giving up of the state intervention in the economy (deregulation), the liberalization of trade and prices and the creation of the legal and institutional conditions for competition.

In different dimensions and indications, during these years of transition appeared many forms of hidden activities like smuggling, the production and marketing of drug plants, prostitution within the country and abroad, the informal credit market, the corruption of a part of the state employees, etc.

As we showed before, the number of businesses increased relatively very fast, but this phenomenon was accompanied by a lot of problems. So, it was with the morality of taxation. To express it more clearly, the problem here is the attitude of the "players" of the informal economy (but, not only they) towards the legal obligation to pay taxes and social security to the state. The results of research carried out about two years ago showed that the majority of the people interviewed (nearly 90 percent of them) did not pay taxes. The rest admitted that they paid, implying here social security in the state enterprises and institutions 
where they have their "first job". This becomes clearer from some approximate calculation of the percentage of the payments for social security and taxes in the total incomes of the family. (For the people interviewed this percentage was very little, 6 percent of the incomes; from which 4 percent were from the incomes of the job they had in the state and only 2 percent from the incomes of self-employment)

A high level of development characterizes the informal market in Albania. From this viewpoint, it can be said that it represents a source of development for economic recovery, but on the other hand, it is an obstacle for fast economic development. This sector is a strong reason for the decline of the state income from social security, because the unregistered incomes of private entrepreneurship represent a gross amount of incomes that are not paying their fiscal obligations. It has also reduced the level of wages, has hindered honest competition through private businesses and caused damage to the labor marketcreating so a strata of undefended people. One of the reasons for this situation, excluding the insufficient level of legal education of the entrepreneurs and the fact that the majority of them are at the same time owners and managers, is also the lack of sufficient experience of the fiscal administration body, the insufficient and nonfunctional control of state structures; as well as the presence in this administration of some people who consider their job as a good position to obtain extra incomes and favors.

The reduction of the informal sector and its legalization among others requires a better harmonization of the interests of employees and employers, of entrepreneurs and the government. A major role is expected to be played by public education on the one hand and the expanding of local government competencies in the administration of fiscal incomes of business activity on the other hand.

\section{3-Business stimulation according to a long-term and differentiated strategy}

The number of businesses in the production sector is still far away from the opportunities and the demands of actual and future development. The stimulation of these kinds of businesses is a perspective that generates many jobs and increases the possibilities for leaving the crisis behind. From this point of view, we could say that many businessmen want to invest in this still somewhat virgin area, but the policy and the strategy of the development of the country has not played its stimulus role properly.

The capital required to invest in production is generally large compared to trade and the service sector, but the policy of granting is still within its frozen framework. Up to now the priority is given to short-term credit with unsupportive interest rates for these kinds of businesses. It is well-known that the investment return for production lines and factories is longer and for this 
reason long-term credit must take its place and with softer interest rates compared with other non-productive businesses.

Business credit has been in an unsatisfactory level because of ineffective management of credits offered by Albanian banks. Very often, a non-stimulus credit is offered i.e. short-term credits with a high interest rate. The business is not treated in a differentiated way and according to a long-term strategy of country development. The short-term credit has prevailed over the long-term one (their ratio has been 1:2 in favor of short-term credit). Perhaps this kind of credit policy, biased toward the short-term has been influenced by the undercapitalization of banks and the lack of sufficient guarantees for a secure return of the credit offered to businesses. If we see this issue from the viewpoint of business management, we can say that several businesses have been in a privileged position because of individual preferences and not of merit and a policy of strategic country development. So a part of businesses taking advantages from the weak control of banks, too, "invested" in the pyramid schemes the credit they obtained from banks instead of using it for "nourishing and growing" their activity. Instead of profits through honest competition, those businesses were oriented in profiting in other ways, even without working. The worst thing of this phenomenon was not simply the deviation from profiting in rivalry with other competitors, but parasitism was stimulated creating the bad opinion that capitalism was easy and anybody can profit a lot even without sweating!

On the other hand, following a protectionist policy for some kind of products and businesses would be stimulating for Albanian investors. Following up a more stimulating policy for domestic production could serve, too, as a support for a more effective management of economic deviation. This deviation actually means that nearly 13-15 percent of the work force lives abroad and more than 25 percent of GDP comes from external (foreign) sources, the capital needed for infrastructure construction is from foreign sources and the demand is mainly oriented towards imported products. This deviation might have positive aspects as well. It might help the reduction of rural unemployment, accelerate development and modernization. But it could have in itself a risk, too. The first danger could be that which happened in Eastern Germany where increasing supply destroyed production capacities. This combined with emigration and liberalization caused non-repairable damages. The danger stands, too, in the fact that in Albania domestic demand does not stimulate local production and this country could be changed into an importer of ready made products. As a consequence, these would increase deficits and foreign debts. Another danger is the possibility of emigration as a result of the unemployment in the rural areas and of urban crises.

With the aim of the development of SMEs and the overcoming of the obstacles and difficulties mentioned above, the role of the state with its supportive 
policies, powerful business infrastructure and with more integrated mechanisms for solving local restrictions, the conditions and the culture are very important

The start-up and the expansion of SMEs are an ongoing process, which require time. It is relatively simple to create a company, but it is very difficult to survive for a certain period of time. Some of the countries support the development of SMEs through a national strategy, while others do not have officially such a strategy, although elements of the policies on SMEs are part of the general economic policies. This happens particularly in those countries where this sector is about 90 percent of the whole economy. The result of these different choices is the setting up of institutions and the usage of different instruments for SMEs development.

The support and development of SMEs are considered an important element of economic growth. In the conditions of Albania, this is particularly important. The Albanian State is conscious of the big role that it has to play in this process through putting together all the efforts and the necessary resources for facilitating and supporting private initiative. Drafting a contemporaneous policy of SMEs development as well as a development strategy, the Albanian state aims to increase the number of small and medium businesses, their contribution to the national economy and the stimulation of small and medium size production enterprises in the sectors with dynamic development. Also, it aims to set up the state mechanisms for supporting these kinds of enterprises from the start-up phase and their further development.

To achieve these objectives, the state must intervene in three directions:

- Financial, through creating a functional system which will guarantee the reimbursement of the credits taken; through using differentiated taxes according to the importance of the activity, as well as the perspective of development; through giving credits under favorable conditions for new businesses.

- Organizational, through supporting the activities of consultancy and management training for the entrepreneurs; through eliminating the discrimination between the private and public sector; through encouraging incubator centers under favorable conditions for business and mainly for those businesses that propose stable development projects; through supporting wholesale firms as a fundamental condition for securing the supply of SMEs which have production activities.

- Institutional, through improving the legal framework especially for SMEs, through securing its implementation; through creating and administrating an efficient information system with access for entrepreneurs; and lastly through creating a national system of consultancy and training centers for small and medium businesses. 
Starting from these conditions, the Albanian State is aiming at supporting small business through drafting the development strategy for this sector. This strategy aims at:

- Creating the conditions for increasing the number of SMEs and strengthening those in existence,

- Increasing financial funds for SMEs with favorable conditions,

- Creating all the facilities for the participation of Albanian entrepreneurs in training,

- Consultancy, information in the area of management, marketing, standards of quality, business organization, organization of production with new technology as well as the increasing of productive capacities and the competition of SMEs in domestic and foreign markets, too.

\section{4- Free Economic Zones}

Albania desperately needs jobs that are more meaningful. The workers are skilled and their labor cost extremely low. Albania must attract foreign firms, which can take advantage of its cheap labor and national resources. These firms must be allowed to freely export their products to other countries, as an incentive for building their facilities in Albania. Otherwise, the Albanian domestic economy cannot afford them at present. This arrangement may be viewed by some critics as exploiting Albania, but importantly, it will create not only needed jobs for Albanian workers, but it will also lead to work experience, training, and know-how in modern companies. Concurrently, free economic zones will create pockets of badly needed industrial infrastructure transportation, communications and utilities.

\section{5- A showcase in Tourism}

A particularly promising development area for Albania is tourism. In addition to its beautiful mountains and beaches, which are within three hours flying time of most major European cities, Albania has numerous historical attractions.

\section{6- Aggressive training of Young Professionals.}

The future of Albania rests on the shoulders of its young people. Many young people have, and still are trying to pursue, a better future by trying to leave Albania. However, giving a ray of hope to young professionals, quality education and training would seem to be extremely valuable.

\section{7- International integration of the Albanian Economy.}

Integration generates two welfare effects, trade creation and trade diversion. Trade diversion results from price competition that will divert trade from former trading partners in non-member countries. Trade creation occurs when cheaper 
supplies may be obtained from member countries at the expense of domestic producers.

The welfare effects of integration for Albania appear impressive. Trade creation will stimulate domestic production to satisfy higher priced foreign markets. Domestic production is so low that trade could hurt some current domestic producers. Albania stands primarily to benefit economically from economic integration - particularly with Western Europe - according to traditional comparative advantage theory. Trade diversion from current partners is unlikely to constitute significant costs because Albania's two largest importers are Italy and Greece, countries which are keen to bolster Albania's economic and political stability. Indeed, such public goods hold a high value in the wake of NATO bombing in March and April.

The benefits of economically integrating Albania to the EU and other Western economies are intuitive and the potential for increasing trade links is apparent in theory and empirical evidence from other regions. However, Albania's weak institutional environment still constitutes a significant obstacle to linking markets. Investments are simply not secure. Transparent, value-added production enterprises that generate regional and foreign exchange and contribute to economic growth have not emerged in Albania. Convoluted property rights and an ineffective judiciary render investments extremely risky. Integration with the EU also offers specific challenges as witnessed by Albania's attempts to accede to the WTO. Accession may be frustrated by the European Union support of certain sectors, particularly agriculture.

Albania's European neighbors would benefit directly from enhanced trade and a larger market, but more importantly, they would benefit from the political stability brought on by a richer Albania. Albania would especially benefit, as it will substantially increase the level of wages and the rate of growth.

The major obstacle is institutional reform. However, given the immense benefits proffered by integration, means must be explored to find mutually beneficial arrangements to innovating joint institutions to generate the surplus that creates value and improved relations.

Despite the achievements and the predisposition of actual government, the success of fully overcoming the crisis as well as the continuation with confidence on the road of further democratic transformation in the economy and in the whole life of our society, will depend precisely on these three factors:

\section{First, the level of public confidence in the government and its reforms.}

Since the election of June 1997, the confidence of the public towards the government has shown signs of decline, which was reflected in the resignation of the government followed by another left-wing government. During this year many things happened; the European and American government together with 
international institutions expressed their confidence in the government, but the process of reforms and above all the level of people's well-being have not advanced, if not declined. And the indicator of well being is a resultant force that shows better than anything the level of confidence of the public towards its government.

\section{Second, full public order}

No improvement in the economic life and in the level of well being can be real if it is not accompanied by full public order. This is closely linked with the prosperity of the economy, with the high level of courage and initiative of the businessmen and in general of the domestic and foreign investors. Smuggling and other aspects of fiscal evasion are present despite the big efforts of the government. One thing should be emphasized here: things will not change much if the center that gives birth to such phenomena is not eliminated. It is too difficult to cut off the way of crime with legal means in a country where three quarters of the population live in poverty. Even states with strong democratic traditions and with a high level of law implementation would not be so successful if they did not fight with economic means that center that is the main cause of crime: poverty. So, the number of unemployed people in the economy is more than 245 thousands. On the other hand, the minimal wage for a state employee is no more than 28 percent of the calculated life minimum level, while the average wage is only 41.5 percent of this life "minimum". If this analysis is continued with the comparison of the wages in some countries in transition, we see that in these countries (table 4) the average wage is from 2-6.5 times higher than that of Albania.

\section{Third, a fair political game according to European standards}

To characterize this ridiculous war between Albanian politicians in the poorest country in Europe, one Albanian author has said that we can compare Albania with a ship in danger of sinking, while the crew (the politicians) is divided into two parts fighting who will be the master of the ship. It seems that their fight probably will be finished before the winner is declared, because a ship waiting for a captain will not survive for a long time. Have the politicians understood that they are fighting a battle without winners at a time when they must work together to save the ship from sinking and then, too, must work together to reconstruct the ship to sail safely into the "democratic sea"?

Table 4: Comparison of wages in some countries in transition

\begin{tabular}{|l|c|c|}
\hline Countries & Monthly wage in \$ & $\begin{array}{c}\text { Growth in percentage } \\
\text { (Albania 100\%) }\end{array}$ \\
\hline Poland & 329 & 658 \\
\hline
\end{tabular}




\begin{tabular}{|l|c|c|}
\hline Czech Rep. & 316 & 632 \\
Slovakia & 256 & 512 \\
Hungary & 246 & 492 \\
Russia & 185 & 370 \\
Bulgaria & 126 & 252 \\
Romania & 100 & 200 \\
Belarus & 95 & 190 \\
Ukraine & 55 & 110 \\
Albania & 50 & 100 \\
\hline
\end{tabular}

Source: Albanian Observer NR 7-8. 1997, Tirana, p 22

Many people in Albania think that this generation of politicians should be changed with politicians of a young generation. It is better to have inexperienced politicians who make mistakes from lack of experience but unconsciously, than politicians with an old spirit who dream only of their seats and themselves at the top of the state. The new government composed by some new politicians, exstudents of December 1990 who took part in the movement that brought about the overthrow of communism, are a hope, but it is very difficult for Albanians to believe them. Another new politician as a Prime Minister replaced this government after a year. But let us wait with the hope that something will change in this country and that the people will have a better future- that which it deserved a long time ago.

\section{References}

Bozdo, A. (1997): Brief Historical Overview on the Development of Money Lending Companies. Presentation on the Conference of Banking Systems Reforms, Tirana, 1213 December 1997.

Culi, D. (1996): Albania: Image and Reality, in: Passage to the west, pp. 138-142, IFAW.

Duka, R. /Harshova, A. (1997): The Bad Loans and Non-Perform Loans: Case of Bank System of Albania. Presentation on the Conference of Banking Systems Reforms, Tirana 12-13 December 1997

Ibrahimi, F. (1997): The role of Monetary Politics in the stabilization and Economic Growth. Presentation on the Conference of Banking Systems Reforms, Tirana, 12-13 December 1997.

Luthans, F. /Lee, M.S. (1994): There are lessons to be learned as Albania undergoes a Paradigm Shift, in: The International Journal of Organizational Analysis, Vol. 2, No 1, pp. 5-17. 
Martin, M. /Kume, V. (1999): International Integration of the Albanian Economy. Presentation on the Conference: Social-Economic development of Albanian Sites and their European Integration. Tirana, November 1999.

Muço, M. (1996): An Overview in the Economic Reform in Albania, in: Passage to the west, pp. 45-50, IFAW.

Nika, E. /Shabani, E. (1997): The Regulatory Framework: A Key Element in the Reform of the Financial Sector. Presentation on the Conference of Banking Systems Reforms, Tirana, 12-13 December 1997.

Preçi, Z. (1997): The Beginnings of Free Market Economy in Albania (reflections), in: The Economy and Transition, No 2, Tirana.

Ruli, G. /Stringa, O. (1997): The restructuring of the Banking System: Problems and Impacts on the Effectiveness of the Monetary Policy. Presentation on the Conference of Banking Systems Reforms, Tirana 12-13 December 1997

Samsom, I. (1996): Albania's Experience among transition trajectories, in: Passage to the west, pp. 20-23, IFAW.

Stringa, A. / Reca, F. (1997): Loans not paid in Time. Presentation on the Conference of Banking Systems Reforms, Tirana, 12-13 December 1997. 